University of Pennsylvania Carey Law School

Penn Carey Law: Legal Scholarship Repository

Faculty Scholarship at Penn Carey Law

10-23-2022

\title{
Border Orientation in a Globalizing World
}

Beth A. Simmons

University of Pennsylvania Law School

Michael R. Kenwick

Rutgers University - New Brunswick/Piscataway

Follow this and additional works at: https://scholarship.law.upenn.edu/faculty_scholarship

Part of the Defense and Security Studies Commons, Human Geography Commons, International Law Commons, International Relations Commons, and the National Security Law Commons

\section{Recommended Citation}

66 Amer. J. Poli. Sci. 853 (2022).

This Article is brought to you for free and open access by Penn Carey Law: Legal Scholarship Repository. It has been accepted for inclusion in Faculty Scholarship at Penn Carey Law by an authorized administrator of Penn Carey Law: Legal Scholarship Repository. For more information, please contact PennlawIR@law.upenn.edu. 


\title{
Border Orientation in a Globalizing World*
}

\author{
(Forthcoming, American Journal of Political Science)
}

\author{
Beth A. SimMONS \\ ANDREA MitCHELL UNIVERSITY PROFESSOR OF \\ LAW AND POLITICAL SCIENCE \\ UNIVERSITY OF PENNSYLVANIA \\ 3501 Sansom St, Philadelphia, PA 19104 \\ simmons3@law.upenn.edu
}

\author{
MiCHAEL R. KENWICK \\ ASSISTANT PROFESSOR \\ RUTGERS UNIVERSITY
}

89 George St. New Brunswick, NJ 08901

michael.kenwick@rutgers.edu

Running Title: Border Orientation in a Globalizing World

Keywords: Border politics, border security, border wall

\footnotetext{
${ }^{*}$ This work was supported by the National Science Foundation, award number 1917573. We are grateful to the following organizations for supporting this project: Perry World House University of Pennsylvania; Carnegie Foundation, Radcliffe Institute, Harvard University; Institute for Quantitative Social Science, Harvard. We are indebted to the following individuals for constructive advice and feedback: Scott Abrams, Nazli Avdan, Erin Baggott, Resat Bayer, Austin Carson, David Carter, Chris Fariss, Hein Goemans, Kerim Kavakli, Benjamin Laughlin, Boram Lee, Aila Matanock, Richard McAlexander, Sara McLaughlin Mitchell, Helen Milner, Jacob Montgomery, Glenn Palmer, Paul Poast, Nicholas Sambanis, Robert Shaffer, Kevin Royning, Zhanna Terechshenko, Shane Wery, Kelebogile Zvobgo. This work benefitted immensely from research assistance by the Borders and Boundaries research teams at Rutgers University and the University of Pennsylvania, including Ryan DelGaudio, Sumin Lee, Burcu Kolcak, Justin Melnick, and Jamie Wang, among many others.
} 


\begin{abstract}
Border politics are a salient component of high international politics. States are increasingly building infrastructure to 'secure' their borders. We introduce the concept of border orientation to describe the extent to which the State is committed to the spatial display of capacities to control the terms of penetration of its national borders. Border orientation provides a lens through which to analyze resistance to globalization, growing populism, and the consequences of intensified border politics. We measure border orientation using novel, geo-spatial data on the built environment along the world's borders and theorize that real and perceived pressures of globalization have resulted in more controlling forms of border governance. Empirical evidence supports this claim: states build more along their borders when faced with economic, cultural, and securitybased anxieties. Border orientation enhances the study of border politics, complementing the politics of territorial division with a richer politics of liminal securitization and its consequences.
\end{abstract}

\title{
Word Count: 9,815
}

Verification Materials:

Replication Materials: The data, code, and any additional materials required to replicate all analyses in this article are available on the American Journal of Political Science Dataverse within the Harvard Dataverse Network, at: https:// doi.org/10.7910/DVN/RRVOJZ. 
Borders are an increasingly salient component of national and international politics. States have historically fought bloody battles to establish their authority over space; for this reason, territorial conflicts are commonly cited as one of the most important causes of war (Senese and Vasquez 2008). Fairly recently, however, states' authoritative peacetime border displays have become increasingly controversial. Globalization of markets and intensified human mobility increasingly challenge political authority and raise questions of cultural identity. Possibly in response to intensifying global pressures, some states employ highly visible strategies of territorial legitimation (Brown 2010) by asserting their control over physical space. In some cases, border control has become a central policy lever in response to a range of perceived external state and non-state threats.

Scholars have few organizing conceptual frameworks to systematize the study of territorial authority in the modern era. The most advanced research program centers on territorial claims, where states compete over border location (Schultz 2015, Allee and Huth 2006). The continued pursuit of this research agenda is vital to our understanding of territorial politics but leaves aside many salient issues that persist even when a border is settled. We propose a paradigm-shifting focus to the question of governance along international borders (Longo 2017b, Simmons 2019). Making this shift requires an organizing conceptual framework for ascribing meaning to expressions of state authority at the border. We therefore introduce a new concept we label border orientation, which taps the State's commitment to the public, authoritative, and spatial display of its capacities to control the terms of penetration of its national borders, often in response to perceived vulnerabilities to external "threats" from state and non-state forces.

Though a state's border orientation cannot be observed directly, it can be approximately inferred by major physical investments at the border. These spatialized investments reflect how states attempt to filter and project their authority along the edges of their sovereign territorial jurisdictions, 
signaling their commitment to rule spatially. ${ }^{1}$ The built environment represents a concrete effort functional and symbolic - to control the terms of entry into, and potentially exit from, a national jurisdiction. These features constitute perimeter and access systems that can be analyzed as expressions of state authority. International borders, like other political spaces, are governed using infrastructure, which routinize how information and commands are transmitted by the State. The built environment is therefore an especially important cue for understanding a state's border orientation.

Border orientation is important to the study of politics because borders are fundamental institutions of governance. Indeed, borders are "meta-rules," in the sense that they define the space over which other rules and policies apply. Internationally, they constitute the units of the state system. Domestically, a state's border presence attempts to assure citizens of the State's ability to supply security, to make and enforce rules, and to deliver or deny services. These aspects of spatial governance speak to the very legitimacy of the territorial state itself.

Border orientation can be documented empirically on a global scale. Using new data on border crossings, border barriers, and border-zone law enforcement stations, we construct and validate a hierarchical latent variable model that generates estimates of border orientation along a unidimensional scale corresponding to permissive border orientations, where little infrastructure is built, to controlling orientations where the presence of filtering infrastructure is intense. Using this concept of border orientation, scholars of comparative and international politics will be able to assess an important spatial aspect of governance.

Our empirical analyses confirm conventional wisdom and suggest new insights. Recent decades have witnessed heightened commitments to border security. Most intriguingly, our findings suggest cultural, economic, and security fears are robustly associated with more controlling

\footnotetext{
${ }^{1}$ Here we are concerned with conceptually defining and measuring border orientation; we leave to future research the question of whether these spatial investments are effective or efficient (Allen, Dobbin, and Morten 2018).
} 
orientations. We also find strong links between controlling orientations and the recent surge in populism experienced by many countries. Border orientation is a useful lens through which to explore a range of national anxieties, aspirations, and capacities and to interrogate spatialized governance in the context of globalization.

\section{International Borders and State Authority}

\section{Borders and legitimate governance}

The establishment of international borders has always been a foundational aspect of modern state legitimacy (Herz 1957). It is difficult to conceive of the territorial state without theorizing its borders as technologies to help legitimate its right to govern space. Territorial delineation, nationstatehood, and the formation of the modern state system were largely co-constitutive processes (Sahlins 1989, Atzili and Kadercan 2017). Indeed, territorial boundedness has become part of the definition of what it means to be a nation-state. Territorial integrity now constitutes a core norm of international relations (Zacher 2001).

For modern states, the international border is the ultimate symbol of sovereignty (Baud and Van Schendel 1997, 226). It defines the space over which states claim the monopoly of the legitimate use of physical force (Weber 1919) and in which they legitimately make, administer, and execute law (Baudet 2012, 32). Moral claims to territory, at least in liberal theory, rest on the legitimate right to govern (Buchanan and Moore 2003, 6). In his sweeping historical account of borders, Maier (2016, 78) writes that "Sovereignty, ownership, and morality came with the territory literally and figuratively."

Unsurprisingly then, threats to border control are understood by some state officials and domestic groups as threats to the state itself. Similarly, national borders are likely to be viewed by dominant but vulnerable domestic groups as a way to secure their local culture and protect a cherished 
way of life. A "borderless world" (Ohmae 1990) worries nationalists of many stripes. Economic integration and technological innovation have contributed to the sense that state boundaries are of vanishing relevance. Transnational threats - from insurgencies to terrorism to cyber threats - are said to have "de-bordered" national security in new ways (Goodman and Portnoy 2009). National security threat assessments in the 1990s for the first time began to place transnational organized crime near the top of the list. ${ }^{2}$ The metaphor of a networked world displaced that of a territorialized and politically bordered one (Castells 2000) - a shift that has not universally been experienced as positive Indeed, in some countries these developments are viewed as a conspiracy of elites corruptly dodging investments at home.

Human mobility in particular is increasingly interpreted as a source of threat to ontological security, or a stable sense of national, group or individual identity (Mitzen 2006), People living in countries other than that of their birth constitute between 3 and $3.25 \%$ of the world's population. ${ }^{3}$ About 25.4 million people were forced to flee their countries and live abroad as refugees in 2017; another 3.1 million presented themselves at foreign borders as official asylum seekers. ${ }^{4}$ Borderlands have (re)emerged as the epicenter of national identity politics (Wilson and Donnan 1998).

We do not contend that these trends "cause" human insecurity. We make the lesser assumption that they are plausibly experienced as such by some groups in some states. ${ }^{5}$ Moreover, threats blur and merge, so that it is unproductive to distinguish traditional issue categories: in the

\footnotetext{
${ }^{2}$ In 1995, Presidential Decision Directive-42 (PDD-42), created by President Clinton, recognized Global Organized Crime as a threat to national security. Available at https:// fas.org/ irp/offdocs/pdd/pdd-42.pdf.

${ }^{3}$ United Nations (UN), bttp:// www.un.org/en/development/desa/population/migration/publications/migrationreport/docs/MigrationReport2017_Highlights.pdf. (Accessed 5 August 2018.)

${ }^{4}$ United Nations High Commissioner for Refugees (UNHCR), bttp:/ / www.unhcr.org/enus/statistics/unhcrstats/5b27be547/ unhcr-global-trends-2017.html. (Accessed 5 August 2018.)

${ }^{5}$ A rich literature has developed over the past two decades exploring how territorial states battle transnational forces they cannot easily control. That literature describes new forms of bordering (Sassen 2008), "invisible" borders (Goff 2000), "exported" borders and "rebordering" (Herzog 2014, Rumford 2006, Andreas and Biersteker 2014).
} 
popular imagination, terrorism merges with migration, security with deindustrializing trade competition, rebel threats with foreign interventions. Since states' legitimacy is based on their territorial claim to rule, they have good reasons to meet a wide range of external governance challenges with visible border policies. This is understandable, since international borders are among the most globally recognized and revered institutions of any in human social relations (Diener 2012). There is no clearer response to the global governance challenges to the modern nation-state than to invest in visible symbols, structures and practices that signal state control at the border. Such investments are deeply bound up with the project of legitimating the state itself, even in parts of the world where effective control is illusive (Chalfin 2010). One implication of this theory of the territorial state is that symbolic as well as functional strategies will increase alongside processes of globalization (Rudolph 2005, Brown 2010). Yet, political science lacks a conceptual and analytic framework for understanding, let alone measuring, these challenges to territorial governance.

\section{The Concept of Border Orientation}

Our purpose is to introduce such a framework, and to demonstrate that it can be meaningfully conceptualized and measured. We suggest the notion of "border orientation," defined as the extent to which the State is committed to the public, authoritative, and spatial display of control over territorial entry and exit at its national borders. A state's border orientation can range from relatively permissive to controlling. Permissiveness is characterized by a willingness to allow the movement of goods and people to proceed across borders unchecked. Controlling orientations, by contrast, seek to project filtering capacity, even while simultaneously facilitating desired transnational trade or human movement. Such a state will want to publicly and visibly display its ability to permit entry of goods and people on its own terms. 
Border orientation encodes the methods, practices and styles of establishing state authority in territorial space. Our use of the word "orientation" is analogous to a firm's unobservable "entrepreneurial orientation" which comprises such observable indicators as its research and development expenditures, debt, and competitive aggressiveness (Lumpkin and Dess 1996). "Goal orientation" is used in personality and achievement studies, where it is understood as a "disposition toward developing or validating one's ability in achievement settings" (VandeWalle 1997) as gleaned from subjects' responses to validated personality instruments. An even closer analogy from political science is Caughey and Warshaw's (2016) “overall orientation of state policy” which makes use of 43 indicators of "policy liberalism" to characterize the ideological orientation of the fifty United States. The concept of "orientation" is used in many contexts to denote the positioning of someone or something in relationship to their surroundings, and may encapsulate essential features of both individuals (Fromm 2013) and organizations (Hurley and Hult 1998).

Organizational orientations raise the issue of where these underlying characteristics come from and at what level of analysis they are generated. Just as the literature on entrepreneurial orientation does not attribute it to the individual CEO (Lumpkin and Dess 1996), border orientation typically is not the product of a single leader. It arises from the interplay of societal preferences and domestic institutions that aggregate and propagate actionable values more generally. In liberal polities, border orientation is the product of civil society preferences as refracted through representative institutions. In autocratic states, border orientation can emerge from the preferences of a smaller ruling elite and can actively repress civil society, as the Berlin Wall exemplified. We refer to a state's border orientation as shorthand for the result of this state-society interplay in the context of specific domestic decisionmaking institutions. 
Border orientation is a compound concept that combines the intensity of authoritative display and the location where it is exercised. Theories of spatial governance emphasize the location of infrastructure as a strategic choice with consequences for internal consolidation and development (Boone 2003, Steinberg 2017). Border governance requires a similar treatment in the face of external pressures from globalization. Infrastructures of border control may be justified as protection from unwanted foreign influence, culture, ideologies, violence, disease or other "dangers." State control may also be positively justified as essential to public goods provision, from the rule of law to comprehensive public welfare. Importantly, "controlling" orientations typically do not seek to block all cross-border flows. Rather they signal an anxious domestic audience as well as an audacious international one that The State will determine who and what enters, and on what terms; in other words, the authority to filter.

The spatial character of this authority is central to our concept. We are interested in describing a phenomenon that potentially reinforces, possibly even reifies, the political boundary of the state. The international border is arguably one of the most legitimate locations for such display. Filtering unwanted foreign goods and people can certainly be exercised internally, but it is often criticized as an encroachment on civil liberties. It can also take place extraterritorially - in foreign airports, at sea, even on the sovereign territory of other states - but at the cost of accusations of imperialism and coercion (Longo 2017a). International law and norms support the common conception that every state has the right to "defend its borders" at the border. To do so is nearly synonymous with making existential legitimacy claims.

The concept of border orientation also includes an aspect of "logistical power" - a form of power that derives from shaping and controlling the physical world (Mukerji 2010). The ability to filter the mobility of people and goods "is premised on infrastructural strength that operates through 
increasingly territorializing means" (Martin 2012). We conceptualize physical border structures as a means to display and exercise political authority.

We define border orientation along a single dimension based on filtering of entry and exit to and from the national territory, whether aimed at the entry of armies, products, migrants, or violence. Moreover, border orientation is typically sticky over time. While political rhetoric or policy fluctuations may change in response to emergencies or sudden shifts in political pressure, a commitment to state presence at the border often requires the development, deployment and maintenance of significant resources and is typically observed over years, rather than days. Investments often accumulate with time, but they also deteriorate and are sometimes purposefully dismantled, as were many of the border controls in what is now the Schengen area.

Border orientation can be conceptualized at multiple levels, the highest of which reflects a state's national orientation toward its set of neighbors. Some states seek to project more control over borders with particular neighbors; for example, United States arguably goes to greater lengths to display control along its southern border than it does in the north; in coordination with other Schengen countries, Poland displays much more state authority along its eastern border with Belarus and Ukraine than the border with Germany to the west. Border orientation may also vary locally along a single border. Some states that are highly committed to projecting border authority generally may have exceptional crossings where state presence is low (Big Bend National Park where Texas borders Mexico is an example). ${ }^{6}$ Some borders, such as northern Chile and southern Peru have well-appointed border crossings (e.g., that at Tacna and Arica) but no off-road fencing at all, rendering ambulatory evasion simple. ${ }^{7}$ The higher a state's overall orientation, however, the rarer such variance will be. Just as the ideology of a political official can be thought of as the proportion of "left" or "right" votes

\footnotetext{
${ }^{6}$ Site visit, June 2017.

${ }^{7}$ Site visit, July 2019.
} 
they cast - i.e., a congressional DW nominate score (Poole and Rosenthal 2000) - border orientation can be thought of as the proportion of a state's border or borders where it seeks to project its presence. In short, while border orientation can be conceptualized as a general characteristic of a state, it also has a dyadic, and even a local component.

Authoritative display is not inherently utilitarian. It often has a symbolic element. Flying a national flag over a port of entry is an obvious example. Border walls and fences too are often symbolic rather than strictly functional (Brown 2010). For whom is the display intended? It may be directed primarily to foreign audiences, signaling welcome, efficiency, or a determination to deter. Or the display may primarily be intended to signal protection or competence to a domestic audience. Such displays often have a Janus-faced quality, communicating to internal and external audiences simultaneously. Importantly, we focus on displays, but are agnostic about their effectiveness.

Strictly speaking, border orientation is not a measure of whether a border is open or closed to transnational traffic. A controlling border orientation is fully consistent with a liberal trade regime for licit goods (e.g., NAFTA liberalizes trade while the US tightly controls its southern border.) Nor do we consider covert filtering technologies such as invisible sensors or landmines to constitute public display. States sometimes outsource border management to non-state actors, from private security firms to the volunteer sector to international organizations, but here our focus is on public bordering expressions by the state's central government and/or its official agents.

A state's border orientation is latent - it cannot be observed directly. The best proxies are fundamental authoritative investments at and near the border, which are crucial visual indicators of a state's commitment to border control. We recognize the built environment is not a perfect indication of orientation. Resource constraints may lead to underestimation, since it is possible states might invest more to assert their authority on their borders if they could afford to. Similarly, there may be 
less need to display authority on mountainous borders that few will observe or attempt to penetrate. Nonetheless, fundamental authoritative investments are a useful indicator of a state's orientation toward controlling territorial entry and possibly exit.

Figure 1 presents border orientation along a unidimensional spectrum. At one end states demonstrate little control over their borders - perhaps only delimiting and demarcating them. In the extreme, it is hard to determine the existence of an international border on the ground at all. We describe this orientation as "permissive" in the sense that few attempts are made to visibly display control or filter movement at the border. The opposite is true at the other extreme, where orientation is highly controlling. These states make great investments to demonstrate control over their borders, which are often marked with walls, fences, and other physical structures. The claim is not that such efforts represent a closed border or exist to stifle movement; rather this end of the spectrum displays the authority to enforce border filtering.

\section{Data: Collecting Information on the Built Environment at the Borders}

To explore border orientation, we have created an innovative dataset of observable physical investments at the border. These are of three kinds: architecture at each land port of entry, infrastructure built along each side of a territorial land border including every wall or substantial fence built parallel and proximate to the border, and the relative density of police stations in the border zone (Table 1).

\section{Access Points: Border Crossings}

Border crossings are the spaces where states may implement a mix of policies, structures and symbols that connect and separate, that facilitate exit and entry selectively. To identify border crossings, we used American Geosciences Institute data to identify major highways connecting pairs of 
contiguous countries. ${ }^{8}$ We overlaid this highway database on a political map of the world to isolate intersections (border crossings) before validating visually. ${ }^{9}$ These crossings generally reflect places where motorized vehicle can cross the border, usually with at least one paved lane each way. If a road approaches but does not cross the border it is deleted as a false positive. For each border crossing, visual inspections using both high altitude and street view images were made to characterize the built environment on each side per Table 1, distinguishing State A and State B.

While Appendix D (pg. 12-15) gives the criteria in detail, Figure 2 depicts two extreme examples. The United States has invested tremendously in symbols and capacity to filter activities at many of its border crossings with Mexico. Inspection stations, barriers, and buildings are all arrayed to improve the chances of filtering in this space. Parts of Africa provide a stark contrast, as shown by a remote border crossing between Burkina Faso and Togo. Importantly, we do not assert that we can tell exactly the nature of the threat states intend to disrupt through these efforts. However, we do infer an intent to signal the authority and capacity to control a border configured as shown in Figure 2a.

Based on these criteria, we produced a dataset of 828 total border crossings with 20 yearly observations. The visual corpus from which Figure 2 is drawn is massive but limited in important ways. Satellite images are generated in response to demand, so some parts of the world have clearer and more numerous images than others. Existence of a crossing requires that a highway be included in the underlying roads dataset, which is primarily based on roads as of $1997 .{ }^{10}$ Images of the built environment were coded between 2000 and 2019, with image quality and coverage improving over

\footnotetext{
${ }^{8}$ United States National Imagery and Mapping Agency. Documentation and definitions are available at at http:// www.agiweb.org/pubs/globalgis/metadata_qr/roads_qk_ref.html.

${ }^{9}$ Using latitude/longitude coordinates generated by the overlay exercise, human coders used Google maps, Bing, and Yandex to located and code each crossing. We eliminated instances where all assigned coders failed to confirm a crossing.

10 These are an adequate sample since we are not primarily interested in the building of roads, but rather the authoritative filtering structures on those roads.
} 
time. Because of uneven coverage of satellite imagery data (observations are available irregularly, and typically not yearly), we forward and backward interpolate the data, assuming that border crossing structures present in the first observed year existed prior to that date and continued to exist until subsequent observation periods.

\section{Perimeters: Walls and Fences}

States have recently started to erect walls at an accelerated rate (Hassner and Wittenberg 2015, Carter and Poast 2017, Vallet 2016). The stated justification for building walls is varied, but often reflects a desire to directly block unwanted movement across a significant portion of the border region, be it the movement of armed forces, migrants, criminal organization, or illicit materials. The presence of walls is typically justified as an attempt to deny illicit forms of entry or exit in the border region, instead funneling movement toward legal ports of entry where active filtering can take place.

We use Carter and Poast's (2017, 248-250) data to identify continuous border structures intended to "prevent entrance by any unwanted entities" (248). Like the original authors, we refer to all structures in this data set as "walls" though it also records structures that are better defined as fences and defense lines. In 2014, the most recent year for which these data are available, there were 45 recorded walls, though recent research suggests this number has increased in recent years. Given right-censoring, we assume any walls present at that time continue to exist.

\section{Border zones: Police Stations}

Finally, we consider the possibility that police have a role in displays of border control. While they are structured differently across countries - some are centrally controlled at the state level, others are localized; some are civil while others are closely connected to the national military - policing 
institutions are a "special source of the state's monopolization of legitimate force on its territory" (Reiner 2010). Peter Andreas (2003) has argued persuasively that border security more than ever resembles policing. As such, the location of policing investments is highly relevant to border displays. Border areas have long been associated with smuggling, trafficking and contraband of unwanted goods and people (Dube, Dube, and Garcia-Ponce 2013, Munro 2012). Especially since 9/11, ordinary police have become increasingly involved with the enforcement of state immigration laws, even in states where such responsibilities have traditionally been outside of their job description (Wishnie 2003). Police have become central to the institutionalization of cooperative "integrative border management" practiced in Europe and elsewhere (Bigo 2014). To the extent that the border is viewed as a place where authoritative social control is necessary, police presence at and near the border becomes a priority.

In contrast to border walls and border crossings, investments in policing are made throughout national territory, with population centers a likely priority. We therefore measure police presence in the border region relative to the interior of a state, weighted by population in each area, using geocoded data on police stations world-wide derived from OpenStreetMap (OSM), gathered in July 2020. ${ }^{11}$

These data result from voluntary crowdsourcing, but they nevertheless give a general indication of where police are located. Importantly, these police data are time invariant and we are therefore unable to determine when each police station was built. These data are therefore useful in unpacking cross-sectional variance in police presence, but do not contribute to temporal variation in the measurement model introduced below.

To generate a measure of relative police presence, we begin by drawing a 30-kilometer buffer zone on each side of all international land borders and record the number of police stations per one

\footnotetext{
${ }^{11}$ See: https://wiki.openstreetmap.org/wiki/Map_Features\#Amenity
} 
hundred thousand population within this area. We then compare the density of police stations per population within the interior of a country, excluding coastal zones. Relative police presence is calculated as:

$$
\text { Relative Police Presence }=\frac{\text { border police stations }}{\text { border population }} / \frac{\text { interior police stations }}{\text { interior population }}
$$

where higher values correspond to disproportionate police presence in border zones relative to the interior of a country, controlling for population. In the following section, this measure is divided into a five-category index to adjust for its highly skewed distribution.

\section{Measurement and Validation of Border Orientation}

\section{A Latent Model of Border Orientation}

Border crossing infrastructure, border walls, and borderland police presence are all manifestations of a state's underlying border orientation. Latent variable models provide a principled means for generating estimates of an unobservable concept based on its observable manifestations (Fariss, Kenwick, and Reuning 2019). We construct a Bayesian latent variable model to estimate border orientation at particular border crossings, and for contiguous directed dyads (i.e., each side of an international border) based on these features. The model assigns higher values to border dyads and crossings that contain more infrastructure, according to the indicators outlined above, and lower values when little infrastructure is present.

Because the indicators are measured across differing levels of analysis, we use a hierarchical modeling structure. In the equations below, we index each border crossing $i=i \ldots, N$ and each directed dyad $d=d \ldots, D .{ }^{12}$ The manifest variables, or "items" outlined in Table 1 are indexed $j=$ $j \ldots, J$ and are observed for either a border crossing $i$ or directed dyad $d$ such that $y_{i d j}$ is the observed

\footnotetext{
12 Dyads with no border crossings are omitted from our data.
} 
value of indicator $j$ at border crossing $i$ along a directed border dyad, $d .{ }^{13}$ Finally, the specific integer values an indicator can take on are denoted $k=1 \ldots, K$, such that $K=2$ for dichotomous indicators, $K>2$ for indicators with more than two categories.

Our model generates two estimates of border orientation (the latent trait). The first, $\theta_{i d}$, is an estimate of border orientation at a particular border crossing $i$ along directed dyad $d$, while the second $\xi_{d}$, is a state's overall dyadic orientation toward a particular neighbor. Each of the manifest variables is linked to the latent trait through two conditioning parameters: a "discrimination" parameter $\beta_{j}$ and a "difficulty" parameter $\alpha_{j}$. These are analogous to a slope and intercept or cut point parameters in a conventional regression setting.

The manifest indicators and latent trait are linked through an item response theory modeling structure, which is composed of a series ordered logistic regression functions. These reduce to the two probability equations below, where $\alpha_{j 0}=-\infty$ and $\alpha_{j K}=\infty$ and $F()$ is the cumulative logistic function. Equations 1 and 2 pertain to the probability equations for crossing-level and directed dyadlevel indicators, respectively, as reflected in the absence of the $i$ subscripting in the latter.

$$
\begin{gathered}
P\left[y_{i d j}=k\right]=F\left(\alpha_{j k}-\beta_{j} \theta_{i d}\right)-F\left(\alpha_{j k-1}-\beta_{j} \theta_{i d}\right) \\
P\left[y_{d j}=k\right]=F\left(\alpha_{j k}-\beta_{j} \xi_{d}\right)-F\left(\alpha_{j k-1}-\beta_{j} \xi_{d}\right)
\end{gathered}
$$

The likelihood function for our model can be expressed as:

$$
\mathcal{L}=\prod_{i=1}^{N} \prod_{d=1}^{D} \prod_{j=1}^{J}\left[\begin{array}{l}
\left.F\left(\alpha_{j y_{[i d j]}}-\beta_{j} \theta_{i d}\right)-F\left(\alpha_{j y_{[i d j]}-1}-\beta_{j} \theta_{i d}\right)\right]^{v_{j}} * \\
\left.\left[\alpha_{[d j]}-\beta_{j} \xi_{d}\right)-F\left(\alpha_{j y_{[d j]}-1}-\beta_{j} \xi_{d}\right)\right]^{\left(v_{j}-1\right)}
\end{array}\right.
$$

Where $v_{j}$ is a dichotomous indicator that is equal to 1 if indicator $j$ is observed at the border crossing level and 0 if it is recorded at the directed dyad level, as is the case for the border wall and police data.

\footnotetext{
${ }^{13}$ With the exception of the police data, which is time invariant, all of our indicators are observed annually $t=t \ldots, T$, though we omit this indexing.
} 
All latent variable models must impose constraints to resolve problems of location, scale, and rotational invariance. The latent trait itself has no natural scale and multiple sets of parameter values could fit the observed data equally well. We follow common convention in assigning Bayesian priors to provide the model with sufficient identifying information about the distribution of the latent trait. ${ }^{14}$ We begin by assigning the following hierarchical prior distributions to the latent trait:

$$
\theta_{i d} \sim \operatorname{Normal}\left(\xi_{d}, \sigma\right) \quad \xi_{d} \sim \operatorname{Normal}(0,1) \quad \sigma \sim \operatorname{Half} \operatorname{Cauchy}(0,2.5)
$$

The standard normal prior on $\xi_{d}$ imposes the assumption that the latent trait is approximately normally distributed, with a mean intentionally centered at zero. This resolves the problem of location and scale invariance by indicating an arbitrary point at which the latent trait will be centered, as well as the overall scale of the distribution. The prior assignments for the item specific parameters are:

$$
\alpha_{j} \sim \operatorname{Normal}(0,10) \quad \beta_{j} \sim \operatorname{Half} \operatorname{Normal}(0,3)
$$

The assignment of a strictly positive distribution to the discrimination parameters, $\beta$, resolves rotational invariance and reflects the assumption belief that the presence of physical infrastructure (as proxied through our variables) corresponds to higher (rather than lower) values of the latent trait. ${ }^{15}$ We estimate the models using RStan, a Bayesian modeling program. ${ }^{16}$ Sufficient samples were obtained after running five parallel chains for 3,000 with the first 1,500 from each discarded as warm-up. Traceplots and $\hat{R}$ statistics were consistent with convergence.

\section{Mapping Border Orientation Globally}

Figure 3 displays a global map of the 2018 border orientation estimates, netting out two potential confounders: wealth, which affects the capacity for displays of control, and geography, which

\footnotetext{
14 See Fariss, Kenwick, and Reuning 2020, 359-361 for a more complete discussion of identification.

${ }^{15}$ All pairwise correlations among the manifest indicators are positive, suggesting that this assumption is not restrictive.

16 Stan Development Team (2018). RStan: the R interface to Stan. R package version 2.17.3. http:/ / mc-stan.org/.
} 
affects the need for displays of control. To do this, we simply regressed our border orientation scores on logged GDP per capita and average elevation at border crossings and display the resulting residuals. ${ }^{17}$ Figure 3 therefore displays border orientation after adjusting for the influence of geography and capacity. Border crossings are displayed as dots, color-coded according to the latent trait estimates $(\theta)$ averaged across both sides of the border. Average scores of the border dyad latent trait $(\xi)$ are displayed as lines. Permissive (low) border orientation scores are displayed in green and controlling (high) scores are displayed in red.

The map confirms many intuitions. Within the Schengen area, green borders and crossings signal states' commitments to free internal movement. Evidence of filtering mounts on Schengen's eastern edge. Border crossings in Sub-Saharan Africa are permissive, which cannot be attributed to a lack of resources alone, since the residuals have already stripped wealth from the estimates in this map. South Africa, however, is notably more controlling. Authoritative display wanes along borders that are remote, such as those along the Andes, even after adjusting for altitude.

Figure 4 displays border orientation over time. Borders in most regions of the world have experienced significant increases in official state presence, confirming that globalization coexists with hardening borders. The rate of increase has accelerated in recent years, especially in Africa, Asia, and the Middle East. In North America, elaborate filtering infrastructure already existed at the outset of our temporal domain, though satellite imagery does reveal intensification between 2000 and 2018 . After splitting our sample among autocracies and democracies in 2000, we find that autocracies are increasingly more controlling than democracies. The Schengen zone demonstrates that infrastructural cumulation is not inevitable: infrastructure can be ripped away with a major commitment to doing so.

\footnotetext{
17 These factors explain only about $1 \%$ of variation at the crossing level and $4 \%$ at the dyadic level, such that our original
} and residualized estimates correlate above .95 . 


\section{Validation $^{18}$}

Several steps were taken to validate the measurement model. First, we analyzed model fit through posterior predictive checks by comparing observed data with the parameter estimates generated by the model. In every case, the predicted and observed distributions closely accorded with one another, providing evidence of strong fit. ${ }^{19}$

Second, we assessed our measure's ability to distinguish from adjacent, but distinct concepts (Adcock and Collier 2001). ${ }^{20}$ One possibility is that border orientation is the same concept as international trade control/facilitation. To evaluate whether this is the case, we calculate each country's mean border orientation score and compare this to the World Bank's Trade Across Borders Index, which is a composite of the time and cost for documentary and border compliance to export and import goods. ${ }^{21}$ These two indicators are only weakly related $(\rho=0.158)$, suggesting that control and efficient handling of trade are not incompatible, but nor are they the same concept.

Is our model of border orientation simply capturing development? Logged GDP per capita is only modestly correlated $(\rho=0.192)$, as is national material capability $(\rho=0.171)$. Clearly our measure captures something apart from these concepts. Nor is there a convincing overlap between border orientation and actual immigration policies. Border orientation is only slightly stronger in states with few visa waivers ${ }^{22}$ but does not vary much across dyads with visa waivers and those without. Clearly border orientation is conceptually and operationally distinct from existing concepts and policies.

\footnotetext{
18 This section reports results using our raw, un-residualized version of our measure to allow for closer comparisons to wealth and development indicators.

${ }^{19}$ Investigation of item-specific parameters also suggests the border crossing indicators are weighted most heavily in determining overall orientation scores.

${ }^{20}$ Appendix A (pg. 3) contains bivariate correlation plots pertaining to each discriminant validity check in this section.

21 The World Bank, Doing Business: Trade Across Borders. Available at bttp:/ / mww.doingbusiness.org/data/ exploretopics/trading-across-borders. (Accessed 15 August 2018.)

22 Data from Mau et al. (2015)
} 


\section{What Explains States' Border Orientation?}

Border orientation is a paradigm-shifting concept that facilitates systematic investigation of a broad range of border anxieties in domestic and international politics. Territorial claims and conflicts are not the only source of border insecurity; indeed, this source of insecurity may in fact be on the decline as norms about territorial integrity have strengthened. To state the obvious, the southern U.S. border is among the most controlled in the world, but can hardly be understood by territorial disputes or claims with Mexico. Border insecurities are often unrelated to traditional interstate territorial disputes. We hypothesize that border orientation is driven at least in part by perceived external threats to the social and economic life of "the nation." What is at stake may not be traditional territorial integrity (Zacher 2001), but rather economic and even ontological security: domestic groups' identity as productive and successful members of their cultural and national community.

In this section, we do not aspire to test a fully elaborated causal theory of border orientation, but we do illustrate its potential for understanding contemporary politics with a disciplined investigation of three overlapping threat vectors: cultural threats, economic threats, and traditional security threats. Table 2 presents an analysis of how each relates to border orientation, measured at the directed dyad year. ${ }^{23}$ To account for temporal non-independence, we report results of Prais-Winsten regression models, which assume a first-order autoregressive pattern in errors. Models 4 and 5 are run on limited samples due to the inclusion of covariates with sparse coverage.

Border insecurities appear to go well beyond those investigated in existing international relations research. Cultural identities exert strong boundary-reinforcing influences in almost all model specifications. Culturally homogeneous countries - those with fewer religious, language and ethnic divisions (Alesina et al. 2003) - typically establish a more controlling orientation than those with more

${ }^{23}$ Additional regression analyses are reported in Appendix C (pg. 7-11). 
heterogeneous populations. This points to the possibility that cultural similarity is prized, while signaling that cultural others may be filtered at the border. The models also track the proportion of a country's population that is foreign born, ${ }^{24}$ and whether this proportion is increasing, although these factors are not statistically significant. However, in Appendix C (pg. 7-11) we show that increases in foreign born populations exerts an increasingly strong, positive association in more recent years.

Culturally influenced bordering is evidenced by neighbors' religious differentiation as well, although bordering is more intense within, rather than between, major religions. Two religious (dis) similarity measures are included using the Correlates of War religion data (MaOz and Henderson 2013). Both are related to the largest religious group on each side of a border. "Primary" religious affiliations include Christianity, Judaism, Islam, Buddhism, Hinduism, syncretic beliefs, and animism. The "secondary" level further subdivides Christianity (protestant, Catholic, orthodox, Anglican), Judaism (orthodox, conservative, reform), and Islam (Shia, Sunni). Intriguingly, the secondary level matters most: countries that share the same primary religion (e.g. Christianity) but have a different secondary religion (e.g. Catholicism vs. Protestantism) tend to erect more at their borders, while dyads with differences at both levels are no more or less likely to hold controlling orientations than religiously similar dyads. ${ }^{25}$ In other words, it is not always "clashes" among the world's primary religions (Huntington 2000) that drive border hardening, but narrower differences within the major religions. Iran's borders provide a good example. Border violence including eight years of war with its Sunni neighbor, Iraq, has led to strong fortification along these countries' shared frontier. By comparison Iran's border with Eastern Orthodox Christian Armenia suggests little intent to filter. The border

\footnotetext{
${ }^{24}$ Data from the United Nations (2017) are recorded every five years, 1990-2015, and for 2017. We interpolate data between observation periods and calculate change accordingly.

25 The reference category for all regressions includes countries whose largest religious group is the same at both the primary and secondary level, as well as a small number of observations $(0.72 \%)$ where countries have the same secondary religion but a different primary religion.
} 
between Catholic Republic of Ireland and Protestant Northern Ireland (UK) is an open exception and is maintained as such with conscious effort.

Economic disparities likely generate border anxieties as well. Wealth differentials consistently matter: the larger the wealth gap between a state and its neighbor, the higher our measure of border orientation. The mechanism could involve concerns about inflows of low wage workers and low-cost goods from a neighboring state stoking domestic political pressures for border control. General statewide measures of economic, political or social globalization ${ }^{26}$ also exert a negative influence border orientation. This link between globalization and opened borders may be precisely what has led to some notable instances of backlash, with nationalists in otherwise globalized states attempting to reassert sovereignty in the border region.

To be sure, border orientation has some traditional security explanations as well. Border displays are indeed heavier along the borders of states that historically have had militarized conflicts, as measured by the number of militarized interstate disputes between neighboring states, 1946-1999 (Palmer et al. 2015, Maoz et al. ). The military ceremonies held by India and Pakistan at the Wagah-Attari crossing is emblematic of this interplay between interstate rivalry and border politics. Western Europe's experience demonstrates that the consequences of past conflict are neither inevitable nor irreversible. Second, terrorist attacks, defined as instances where non-state actors threaten or use violence against civilians to intimidate or coerce for political, religious, or economic ends, ${ }^{27}$ are correlated with more controlling border orientations. ${ }^{28}$ By contrast, we found a negative relationship

\footnotetext{
${ }^{26}$ These are de facto measures based on economic, political, cultural and interpersonal sub-indicators. For details see Gygli et al (2019). The economic indicator weights trade and financial integration most heavily. Data available at bttps:/ / www.kef.ethz.ch/en/forecasts-and-indicators/indicators/kof-globalisation-index.html.

${ }^{27}$ Measured as a count of terrorist attacks within a state's territory within the past five years National Consortium for the Study of Terrorism and Responses to Terrorism (START). (2018). Global Terrorism Database [Data file]. Retrieved from bttps:/ / www.start.umd.edu/gtd,

${ }^{28}$ Previous studies have found a similar, positive link between terrorism and the construction of border walls and fences (Avdan 2018) Once built, border walls may reduce the occurrence of terrorism (Avdan and Gelpi 2016) Since in many
} 
between past civil conflict in a neighboring state ${ }^{29}$ and controlling border orientations. We suspect that this result is driven by capacity, as less developed states are likely to share borders with conflictprone neighbors yet lack the capacity to project their presence.

One important finding is a null result: there is little evidence that the traditional conception of borders as territorial divisions explains modern border orientation. There is no direct evidence that the presence of an unsettled or conflicting territorial claim between neighbors significantly impacts border orientation. ${ }^{30}$ These data are limited to three years' worth of observations, which is why we only include the variable in model 4, but the null finding suggests that the usual way of thinking about borders as territorial divisions that are inherently disputatious and potentially threaten state security, are not in fact the central condition associated with investments in the symbols and structures of modern border security.

If modern border orientation cannot be fully explained by traditional state security concerns or staking out claims to territory under interstate dispute, we need an innovative explanation for the trends described with this new data. The cultural and economic findings above suggest broad political movements and ideologies of "othering" contribute to domestic demands for border control. As an additional plausibility probe, we explore the relationship between border orientation one measure of populism. While populism has many contextualized meanings, we test for a conception of populism that represents a "thin" ideology, that distinguishes two homogenous and antagonistic groups: a "corrupt elite" and a "pure people" (Mudde 2017). It "presupposes that the elite comes from the same

cases terrorists enter a country at official crossings rather than overland, our more granular measure may provide a more precise test of this link in future research.

${ }^{29}$ Dichotomous variable for whether the neighboring state is experiencing a civil conflict resulting in at least 25 fatalities in the preceding two decades. Armed Conflict Data (Allansson, Melander, and Themnér 2017).

${ }^{30}$ Data obtained from Frederick, Hensel, and Macaulay (2017). Given the short temporal domain and high degree of autocorrelation, we also supplemented this model with cross-sectional variants, finding no substantive changes in the territorial issue indicator. 
group as the people, but have willingly chosen to betray them, by putting the special interests and inauthentic morals of the elite over those of the people" (Mudde 2017) The "pure people" is a term that is often racially and nationally exclusive. Rodrik (2018) relates the rise of populism to specific global economic shocks: populists from the left are often concerned with combatting threats from trade and investment, while those on the right are often concerned with immigration and refugees. Human mobility, cultural difference and economic integration have arguably sharpened cleavages that make populist ideas increasingly salient. We hypothesize that both functional and symbolic border displays are increasingly attractive under these circumstances.

Model 5 includes the average level of populist rhetoric employed in speeches by presidents and prime ministers using the text-based measure computed by Hawkins et al. (2019). These data are currently available for only 40 countries, including most of the larger countries of Europe, some of the Americas, India and Turkey. Border orientation is not a characteristic of a single political leader, but since the sample for which data are available is fairly democratic, this measure likely reflects broad political currents that have at least some appeal nationally. We take the average score across the entire observation period of 1998-2019 to gain a holistic picture of a given state. The populist rhetoric of leaders is indeed correlated with a state's border orientation in the expected direction. Figure 5 demonstrates a robust bivariate correlation between populism and border orientation, consistent with our conjecture that physical displays at the border reflect anxieties about globalization and cultural Others, at least for a subset of states for whom data are available.

Control variables in Table 2 behave as we would expect. As discussed above, GDP per capita explains a relatively small proportion of the variation in border orientation but nevertheless remains positive and significant across all specifications. ${ }^{31}$ In addition, every model shows that states within the

31 World Bank (2015). 
Schengen zone have relatively low scores, suggesting that border commitments are reversible through institutional arrangements. Though democracies may tend to have more permissive border orientations, this coefficient is neither negative nor significant in most specifications. ${ }^{32}$ A country's border orientation is strongly correlated with that of its neighbor, though several mechanisms could produce this result - competition, emulation, or simply geographic clustering of omitted variables. The average elevation at a country's border crossings has a negative, albeit insignificant coefficient, probably explained by a lower demand for movement and higher costs of infrastructural development.

\section{Conclusion}

Borders are crucial institutions in international and domestic politics. They are important sites of governance and have come to define what it means to be a modern state. International borders have at least as much salience domestically as they do internationally. They delineate the space over which states have jurisdiction; they also delineate the people for whom national public goods - from security to social services to stable political institutions - are to be provided (Goemans 2006). They may even shape the fundamental identity of a people by distinguishing the national from the transnational and the foreign.

All of these possibilities require a much richer understanding of the functions and meaning of international borders than has been typical in political science. Surprisingly little systematic investigation has been made into governments' fundamental orientation toward displays of border control. We suggest that the spatial orientation of governance - how starkly a polity signals control over filtering "us" from "them" - is as important as many of its other governing qualities, such as bureaucratic/administrative competence, civil-military relations, and state/society relations. While interstate territorial conflicts are among the most intractable a state may face, our findings suggest that

\footnotetext{
32 Measured using the 21-point Polity2 index (Marshall, Gurr, and Jaggers 2017). In cross-sectional regressions this variable is negative and sometimes marginally significant (Appendix C 7-11).
} 
modern border politics has less to do with traditional territorial integrity (Zacher 2001), and more to do with perceptions of non-state threats to national sovereignty.

How might the concept of border orientation inform future research? One research agenda should focus on elaborating explanations for border orientation itself. We have focused here on land borders, and controlled for mountains, but further investigation may reveal distinctive geographical features, such as long coastlines, rivers or expansive deserts that might influence border orientation. Additionally, historical context should be more fully explored (Abramson and Carter 2016, Maier 2016, Gavrilis 2008). Historical rivalries, trade routes, imperial and national strategies of expansion and development, and long-established patterns of human settlement likely influence state displays at the border. Much more should be done to understand modern trends as well. If border orientation really is connected in some way to perceived threats of globalization, research should explore the mechanisms through which integrative pressures are translated into preferences and ultimately policy regarding the spatial orientation of state displays of authority.

It may be that border orientation is less about economics and more about various threats to individual or group identity. The two may of course be related, since one important source of identity is employment and occupational status (Carper 2017). Cultural identity, cultural threats, and "we" versus "them" ideologies such as populism, should be explored in greater depth and with multiple methods. The association between surges in foreign-born residents and border thickening should be further tested and probed for the direction of causation, if any. ${ }^{33}$ We suspect cultural explanations would be enriched by theories of distributive politics, with dominant groups who are gradually losing economic and cultural privileges making the loudest demands for displays of border control.

\footnotetext{
33 Cultural identities have both shaped and been shaped by national political borders (Pelkmans 2006).
} 
The richest payoff to studying border orientation will be to understand its consequences. Note that border orientation is a commitment to display authority; effectiveness (which would need to be carefully defined and measured) is not assumed. For policy relevance, it will be important to know whether attention to border control pays dividends - that is, whether it achieves some (un)articulated goal. Does a commitment to filter at the border reduce crime, illicit trafficking, and terrorism (Avdan and Gelpi 2016)? Affect trade (Carter and Poast 2020)? Reduce unauthorized inward migration (Allen, Dobbin, and Morten 2018)? Does a stringent border orientation have unintended consequences send hostile signals to neighbors? Stoke nationalism? Divert rather than reduce transnational crime (Getmanski, Grossman, and Wright 2019)? Encourage delay of costly internal measures in the face of transnational pandemics (Kenwick and Simmons 2020)? Or is it the case that the impact of these investments is largely in the eyes of the beholder, enhancing a sense of psychological, rather than material security? By developing the concept of border orientation at the level of the nation-state, border dyads, and even border crossings and segments, there is now a way to investigate variance on authoritative state displays at the border to shed light on these issues. 


\section{References:}

Abramson, Scott F, and David B Carter. 2016. "The historical origins of territorial disputes." American Political Science Review 110 (4):675-698.

Adcock, Robert, and David Collier. 2001. "Measurement validity: A shared standard for qualitative and quantitative research." American Political Science Review 95 (3):529-546.

Alesina, Alberto, Arnaud Devleeschauwer, William Easterly, Sergio Kurlat, and Romain Wacziarg. 2003. "Fractionalization." Journal of Economic Growth 8 (2):155-194.

Allansson, Marie, Erik Melander, and Lotta Themnér. 2017. "Organized violence, 1989-2016." Journal of Peace Research 54 (4):574-587.

Allee, Todd L., and Paul K. Huth. 2006. "Legitimizing Dispute Settlement: International Legal Rulings as Domestic Political Cover." American Political Science Review 100 (02):219-234.

Allen, Treb, Cauê de Castro Dobbin, and Melanie Morten. 2018. Border walls. National Bureau of Economic Research.

Andreas, Peter. 2003. "Redrawing the Line: Borders and Security in the Twenty-first Century." International Security 28 (2):78-111.

Andreas, Peter, and Thomas J Biersteker. 2014. The rebordering of North America: integration and exclusion in a new security context: Routledge.

Atzili, Boaz, and Burak Kadercan. 2017. "Territorial designs and international politics: the diverging constitution of space and boundaries." Territory, Politics, Governance 5 (2):115-130.

Avdan, Nazli. 2018. Visas and Walls: Border Security in the Age of Terrorism: University of Pennsylvania Press.

Avdan, Nazli, and Christopher F Gelpi. 2016. "Do Good Fences Make Good Neighbors? Border Barriers and the Transnational Flow of Terrorist Violence." International Studies Quarterly 61 (1):14-27.

Baud, Michiel, and Willem Van Schendel. 1997. "Toward a comparative history of borderlands." Journal of World History 8 (2):211-242.

Baudet, Thierry. 2012. The significance of borders: why representative government and the rule of law require nation states: Martinus Nijhoff Publishers.

Bigo, Didier. 2014. "The (in) securitization practices of the three universes of EU border control: Military/Navy-border guards/police-database analysts." Security Dialogue 45 (3):209-225.

Boone, Catherine. 2003. Political topographies of the African state: Territorial authority and institutional choice: Cambridge University Press.

Brown, Wendy. 2010. Walled states, waning sovereignty. New York Zone Books.

Buchanan, Allen, and Margaret Moore. 2003. "Introduction: The Making and Unmaking of Boundaries." In States, nations and borders: the ethics of making boundaries, edited by Allen Buchanan and Margaret Moore, 1-15. New York: Cambridge University Press.

Carper, James. 2017. "The elements of identification with an occupation." In Sociological work, 177-188. Routledge.

Carter, David B, and Paul Poast. 2017. "Why do states build walls? Political economy, security, and border stability." Journal of Conflict Resolution 61 (2):239-270.

Carter, David B, and Paul Poast. 2020. "Barriers to Trade: How Border Walls Affect Trade Relations." International Organization 74 (1):165-185.

Castells, Manuel. 2000. The rise of the network society. 2nd ed. ed. Oxford: Blackwell Publishers.

Caughey, Devin, and Christopher Warshaw. 2016. "The dynamics of state policy liberalism, 1936-2014." American Journal of Political Science 60 (4):899-913.

Chalfin, Brenda. 2010. Neoliberal frontiers : an ethnography of sovereignty in West Africa. Chicago: The University of Chicago Press. 
Diener, Alexander C. 2012. Borders : a very short introduction. New York: Oxford University Press.

Dube, Arindrajit, Oeindrila Dube, and Omar Garcia-Ponce. 2013. "Cross-Border Spillover: U.S. Gun Laws and Violence in Mexico." American Political Science Review 107 (03):397-417.

Fariss, Christopher J, Michael R Kenwick, and Kevin Reuning. 2019. "Measurement models." In SAGE Handbook of Research Methods in Political Science and International Relations, edited by Luigi Curini and Robert Jr Franzese.

Frederick, Bryan A, Paul R Hensel, and Christopher Macaulay. 2017. "The Issue Correlates of War Territorial Claims Data, 1816-20011." Journal of Peace Research 54 (1):99-108.

Fromm, Erich. 2013. Man for himself: An inquiry into the psychology of ethics: Routledge.

Gavrilis, George. 2008. The dynamics of interstate boundaries. Cambridge: Cambridge University Press. Getmanski, Anne, Guy Grossman, and Austin L Wright. 2019. "Border walls and smuggling spillovers." Quarterly Journal of Political Science 14 (3):329-347.

Goemans, H. E. 2006. "Bounded Communities: Territorial Changes and International Conflict." In Territoriality and conflict in an era of globalization, edited by Miles Kahler and Barbara F. Walter. Cambridge: Cambridge University Press.

Goff, Patricia M. 2000. "Invisible borders: Economic liberalization and national identity." International Studies Quarterly 44 (4):533-562.

Goodman, Seymour E., and Michael Portnoy. 2009. Global initiatives to secure cyberspace : an emerging landscape, Advances in information security ; 42. New York: Springer.

Gygli, Savina, Florian Haelg, Niklas Potrafke, and Jan-Egbert Sturm. 2019. "The KOF Globalisation Indexrevisited." The Review of International Organizations 14 (3):543-574.

Hassner, Ron E., and Jason Wittenberg. 2015. "Barriers to Entry: Who Builds Fortified Boundaries and Why?" International Security 40 (1):157-190.

Hawkins, Kirk A, Rosario Aguilar, Erin Jenne, Bojana Kocijan, Cristóbal Rovira Kaltwasser, and Bruno Castanho Silva. 2019. Global Populism Database: Populism Dataset for Leaders.

Herz, John H. 1957. "Rise and demise of the territorial state." World Politics 9 (4):473-493.

Herzog, Lawrence A. 2014. "Globalisation, Place and Twenty-First-Century International Border Regions: An Introduction to the Special Issue." Global Society 28 (4):391-397.

Huntington, Samuel P. 2000. "The clash of civilizations?" In Culture and politics, 99-118. Springer.

Hurley, Robert F, and G Tomas M Hult. 1998. "Innovation, market orientation, and organizational learning: an integration and empirical examination." Journal of marketing 62 (3):42-54.

Jackman, Simon. 2009. Bayesian analysis for the social sciences. Vol. 846: John Wiley \& Sons.

Kenwick, Michael R., and Beth A. Simmons. 2020. "Pandemic Response as Border Politics." International Organization 74(Suppl.): 1-23

Longo, Matthew. 2017a. "From Sovereignty to Imperium: Borders, Frontiers and the Specter of NeoImperialism." Geopolitics 22 (4):757-771.

Longo, Matthew. 2017b. The politics of borders: sovereignty, security, and the citizen after 9/11: Cambridge University Press.

Lumpkin, G Tom, and Gregory G Dess. 1996. "Clarifying the entrepreneurial orientation construct and linking it to performance." Academy of Management Review 21 (1):135-172.

Maier, Charles S. 2016. Once Within Borders: Territories of Power, Wealth, and Belonging Since 1500. Cambridge MA: Belknap Press of Harvard University Press.

Maoz, Zeev, Paul L. Johnson, Jasper Kaplan, Fiona Ogunkoya and Aaron Shreve. 2018. "The Dyadic Militarized Interstate Disputes (MIDs) Dataset Version 3.0: Logic, Charictaristics, and Comparisons to Alternate Datasets. Journal of Conflict Resolution 63 (3): 811-835.

Maoz, Zeev, and Errol A Henderson. 2013. "The world religion dataset, 1945-2010: Logic, estimates, and trends." International Interactions 39 (3):265-291. 
Marshall, Monty, Ted Robert Gurr, and Keith Jaggers. 2017. Data Users' Manual, Polity IV Project: Political Regime Characteristics and Transitions, 1800-2016. Available online at: http://www.systemicpeace.org/inscr/p4manualv2016.pdf.

Martin, Craig. 2012. "Desperate Mobilities: Logistics, Security and the Extra-Logistical Knowledge of 'Appropriation'." Geopolitics 17 (2):355-376.

Mitzen, Jennifer. 2006. "Ontological security in world politics: State identity and the security dilemma." European Journal of International Relations 12 (3):341-370.

Mudde, Cas. 2017. "An ideational approach." The Oxford Handbook of Populism:27-47.

Mukerji, Chandra. 2010. "The territorial state as a figured world of power: Strategics, logistics, and impersonal rule." Sociological Theory 28 (4):402-424.

Munro, Peter. 2012. "Harbouring the illicit: borderlands and human trafficking in South East Asia." Crime, Law and Social Change 58 (2):159-177.

Ohmae, Kenichi. 1990. The Borderless World: Power and Strategies in the Interlinked Economy. New York: Harper Business.

Palmer, Glenn, Vito d'Orazio, Michael Kenwick, and Matthew Lane. 2015. "The MID4 dataset, 20022010: Procedures, coding rules and description." Conflict Management and Peace Science 32 (2):222-242.

Pelkmans, Mathijs. 2006. Defending the border: identity, religion, and modernity in the Republic of Georgia: Cornell University Press.

Poole, Keith T, and Howard Rosenthal. 2000. Congress: A political-economic history of roll call voting: Oxford University Press on Demand.

Reiner, Robert. 2010. The politics of the police: Oxford University Press.

Rodrik, Dani. 2018. "Populism and the Economics of Globalization." Journal of International Business Policy:1-22.

Rudolph, Christopher. 2005. "Sovereignty and territorial borders in a global age." International studies review 7 (1):1-20.

Rumford, Chris. 2006. "Rethinking European spaces: territory, borders, governance." Comparative European Politics 4:127-140.

Sahlins, Peter. 1989. Boundaries : the making of France and Spain in the Pyrenees. Berkeley: University of California Press.

Sassen, Saskia. 2008. "Bordering capabilities versus borders: implications for national borders." Mich. J. Int'l L. 30:567.

Schultz, Kenneth A. 2015. "Borders, conflict, and trade." Annual Review of Political Science 18:125-145.

Senese, Paul D, and John A Vasquez. 2008. The steps to war: An empirical study: Princeton University Press.

Simmons, Beth A. 2019. "Border Rules." International Studies Review 21 (2):256-283.

Steinberg, Jessica. 2017. "'Strong' States and Strategic Governance: A model of territorial variation in state presence." Journal of Theoretical Politics 30 (2):224-245.

UN, Department of Economic and Social Affairs, Population Division. 2017. Trends in International Migrant Stock: The 2017 Revision. Geneva: United Nations database.

Vallet, Élisabeth. 2016. Borders, Fences and Walls: State of Insecurity? New York: Routledge.

VandeWalle, Don. 1997. "Development and validation of a work domain goal orientation instrument." Educational and Psychological Measurement 57 (6):995-1015.

Weber, Max. 1919. "Politics as a Vocation, 1918." From Max Weber: Essays in Sociology (New York: Galaxy Books, 1958):77-128.

Wilson, Thomas M., and Hastings Donnan, eds. 1998. Border identities : nation and state at international frontiers. Cambridge: Cambridge University Press. 
Wishnie, Michael J. 2003. "State and local police enforcement of immigration laws." U. Pa. J. Const. L. 6:1084.

Zacher, Mark. 2001. "The territorial integrity norm: International boundaries and the use of force." International Organization 55 (2):215-250. 
Table 1: Border Crossing Features Collected as Part of Data Collection Effort

\begin{tabular}{ll}
\hline Border Crossing Features & Description \\
\hline (1) Official building(s) & $\begin{array}{l}\text { Codes whether and how many buildings are near the } \\
\text { border that appear to be "official," meaning a state- } \\
\text { controlled border security facility. }\end{array}$ \\
(2) Gate or barricade & $\begin{array}{l}\text { Gates, barriers, or structures that straddle the main road } \\
\text { that itself crosses the international border. Includes } \\
\text { partial structures that appear designed to slow, divert, } \\
\text { inspect, identify or stop traffic. }\end{array}$ \\
(3) Split lanes & $\begin{array}{l}\text { Identifies any change in the roadway to accommodate } \\
\text { search, interdiction, inspection, or pullover areas. }\end{array}$ \\
\hline
\end{tabular}

\section{Border Zone Features}

\section{Description}

(1) Border Wall/Fence

Man-made structures erected across interstate borders with the intention of denying entry of unwanted materials or personnel, recorded at the directed interstate dyad (Carter and Post 2015).

(2) Relative Police Station Density

Location of police stations were obtained from OpenStreetMap. Police density is calculated as the proportion of police stations in border region relative to the interior, both weighted by population.

Note: detailed information on coding procedures are available in Appendix D (pg. 12-15). 
Table 2: Correlates of Border Orientation

\begin{tabular}{|c|c|c|c|c|c|}
\hline & \multicolumn{5}{|c|}{$\begin{array}{c}\text { Dependent Variable: } \\
\text { Border Orientation at the Directed-Dyad-Year Level }\end{array}$} \\
\hline & (1) & (2) & (3) & (4) & (5) \\
\hline \multicolumn{6}{|l|}{ Cultural Anxieties } \\
\hline Cultural Homogeneity^ & $\begin{array}{l}0.163^{*} \\
(0.028)\end{array}$ & $\begin{array}{l}0.168^{*} \\
(0.028)\end{array}$ & $\begin{array}{l}0.166^{*} \\
(0.029)\end{array}$ & $\begin{array}{l}0.209^{*} \\
(0.039)\end{array}$ & $\begin{array}{r}0.009 \\
(0.067)\end{array}$ \\
\hline Percent Foreign Bom Population & $\begin{array}{c}0.002 \\
(0.001)\end{array}$ & $\begin{array}{c}0.002 \\
(0.001)\end{array}$ & $\begin{array}{c}0.002 \\
(0.001)\end{array}$ & $\begin{array}{c}0.003 \\
(0.002)\end{array}$ & $\begin{array}{l}-0.002 \\
(0.003)\end{array}$ \\
\hline $\begin{array}{l}\text { Change in Percent Foreign Born } \\
\text { Population }\end{array}$ & $\begin{array}{l}-0.001 \\
(0.001)\end{array}$ & $\begin{array}{l}-0.001 \\
(0.001)\end{array}$ & $\begin{array}{l}-0.001 \\
(0.001)\end{array}$ & $\begin{array}{l}-0.035^{*} \\
(0.016)\end{array}$ & $\begin{array}{r}0.000 \\
(0.004)\end{array}$ \\
\hline Same Primary Religion Type, Different & $0.025^{*}$ & $0.027^{*}$ & $0.027^{*}$ & $0.259^{*}$ & 0.024 \\
\hline $\begin{array}{l}\text { Secondary Religion } \\
\text { Different Primary and Secondary } \\
\text { Religion Type }\end{array}$ & $\begin{array}{c}(0.012) \\
0.008 \\
(0.026)\end{array}$ & $\begin{array}{c}(0.012) \\
0.003 \\
(0.026)\end{array}$ & $\begin{array}{c}(0.012) \\
0.006 \\
(0.027)\end{array}$ & $\begin{array}{l}(0.051) \\
0.105^{*} \\
(0.051)\end{array}$ & $\begin{array}{c}(0.017) \\
0.075 \\
(0.052)\end{array}$ \\
\hline \multicolumn{6}{|l|}{ Economic Anxieties } \\
\hline Five-year Change in Globalization & & $\begin{array}{l}-0.001^{*} \\
(0.000)\end{array}$ & $\begin{array}{l}-0.001^{*} \\
(0.000)\end{array}$ & $\begin{array}{c}0.000 \\
(0.001)\end{array}$ & $\begin{array}{r}-0.001 \\
(0.001)\end{array}$ \\
\hline $\begin{array}{l}\text { Difference in Logged GDP Per Capita } \\
\text { with Neighbor }\end{array}$ & & $\begin{array}{l}0.036^{*} \\
(0.012)\end{array}$ & $\begin{array}{l}0.040^{*} \\
(0.013)\end{array}$ & $\begin{array}{l}0.060^{*} \\
(0.018)\end{array}$ & $\begin{array}{l}0.156^{*} \\
(0.024)\end{array}$ \\
\hline \multicolumn{6}{|l|}{ Security Anxieties } \\
\hline $\begin{array}{l}\text { Count of MIDs with Neighbor, } 1980- \\
1999^{\wedge}\end{array}$ & & & $\begin{array}{l}0.028^{*} \\
(0.007)\end{array}$ & $\begin{array}{c}0.009 \\
(0.009)\end{array}$ & $\begin{array}{r}0.004 \\
(0.011)\end{array}$ \\
\hline $\begin{array}{l}\text { Count of Civilian Conflicts in neighbor, } \\
1980-1999^{\wedge}\end{array}$ & & & $\begin{array}{l}-0.003^{*} \\
(0.001)\end{array}$ & $\begin{array}{l}-0.003^{*} \\
(0.002)\end{array}$ & $\begin{array}{l}-0.004 \\
(0.003)\end{array}$ \\
\hline $\begin{array}{l}\text { Logged Number of Terrorist Events } \\
\text { (10yr Moving Average) }\end{array}$ & & & $\begin{array}{l}0.000^{*} \\
(0.000)\end{array}$ & $\begin{array}{c}0.000 \\
(0.000)\end{array}$ & $\begin{array}{l}0.000^{*} \\
(0.000)\end{array}$ \\
\hline Territorial Issue & & & & $\begin{array}{l}-0.003 \\
(0.013)\end{array}$ & \\
\hline \multicolumn{6}{|l|}{ Populism } \\
\hline Average Populist Rhetoric Score ${ }^{\wedge}$ & & & & & $\begin{array}{l}0.383^{*} \\
(0.091)\end{array}$ \\
\hline \multicolumn{6}{|l|}{ Control Variables } \\
\hline Logged GDP per capita & $\begin{array}{l}0.049 * \\
(0.011)\end{array}$ & $\begin{array}{l}0.035^{*} \\
(0.012)\end{array}$ & $\begin{array}{l}0.035^{*} \\
(0.013)\end{array}$ & $\begin{array}{c}0.011 \\
(0.019)\end{array}$ & $\begin{array}{l}-0.030 \\
(0.025)\end{array}$ \\
\hline Democracy (polity 2) & $\begin{array}{c}0.000 \\
(0.001)\end{array}$ & $\begin{array}{c}0.000 \\
(0.001)\end{array}$ & $\begin{array}{c}0.000 \\
(0.001)\end{array}$ & $\begin{array}{l}-0.002 \\
(0.001)\end{array}$ & $\begin{array}{l}-0.001 \\
(0.003)\end{array}$ \\
\hline Average Elevation ${ }^{\wedge}$ & $\begin{array}{l}-0.022 \\
(0.021)\end{array}$ & $\begin{array}{l}-0.021 \\
(0.021)\end{array}$ & $\begin{array}{l}-0.013 \\
(0.021)\end{array}$ & $\begin{array}{l}-0.012 \\
(0.026)\end{array}$ & $\begin{array}{l}-0.126^{*} \\
(0.028)\end{array}$ \\
\hline Schengen Zone Member & $\begin{array}{c}-0.052^{*} \\
(0.013)\end{array}$ & $\begin{array}{c}-0.052^{*} \\
(0.013)\end{array}$ & $\begin{array}{c}-0.056^{*} \\
(0.014)\end{array}$ & $\begin{array}{l}-0.025 \\
(0.022)\end{array}$ & $\begin{array}{l}-0.035^{*} \\
(0.016)\end{array}$ \\
\hline Neighbor's Border Orientation & $\begin{array}{l}0.265^{*} \\
(0.011)\end{array}$ & $\begin{array}{l}0.282^{*} \\
(0.011)\end{array}$ & $\begin{array}{l}0.293^{*} \\
(0.011)\end{array}$ & $\begin{array}{l}0.539^{*} \\
(0.022)\end{array}$ & $\begin{array}{l}0.364^{*} \\
(0.018)\end{array}$ \\
\hline Constant & $\begin{array}{c}-0.677^{*} \\
(0.084) \\
\end{array}$ & $\begin{array}{c}-0.569^{*} \\
(0.089) \\
\end{array}$ & $\begin{array}{c}-0.591^{*} \\
(0.093)\end{array}$ & $\begin{array}{c}-0.565^{*} \\
(0.136) \\
\end{array}$ & $\begin{array}{r}0.286 \\
(0.245) \\
\end{array}$ \\
\hline AR(1) Coefficient & 0.968 & 0.966 & 0.964 & 0.995 & 0.961 \\
\hline Durbin-Watson statistic (original) & 0.063 & 0.067 & 0.071 & 0.007 & 0.080 \\
\hline Durbin-Watson statistic (transformed) & 1.808 & 1.808 & 1.805 & 0.9421 & 1.954 \\
\hline Observations & 7596 & 7458 & 6997 & 818 & 2576 \\
\hline
\end{tabular}

Note: ${ }^{\wedge}$ Time-invariant indicator, $\dagger<0.1,{ }^{*} p<0.05$ 
Border Orientation (unobserved trait):

State commitment to the authoritative display of control at the border

No control displayed

Observable indicators of low commitment

- Border crossings are devoid of barriers and inspection stations

- Borders lack fences and walls intended to prevent the movement of people or goods

- Border zones lack police, military and border patrol presence
Ability to filter and block displayed

Observable indicators of high commitment

- $\quad$ States erect physical infrastructure to filter and block movements at border crossings

- Walls and physical barriers are present between formal border crossing points

- Border zones have police, military and border patrol presence

Figure 1: Border orientation is an unobservable state commitment to the authoritative display of control over the terms of territorial entry at or near national borders. 
a. United States and Mexico (Latitude: 27.502377, Longitude: -99.502641)

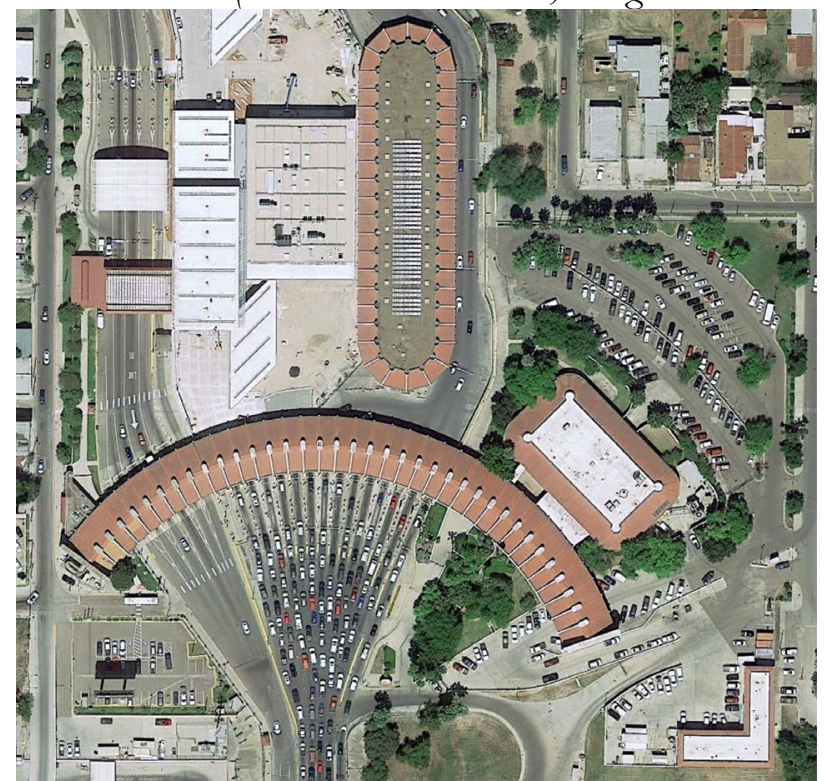

b. Burkina Faso and Togo (Latitude: 10.977377, Longitude: 0.511543)

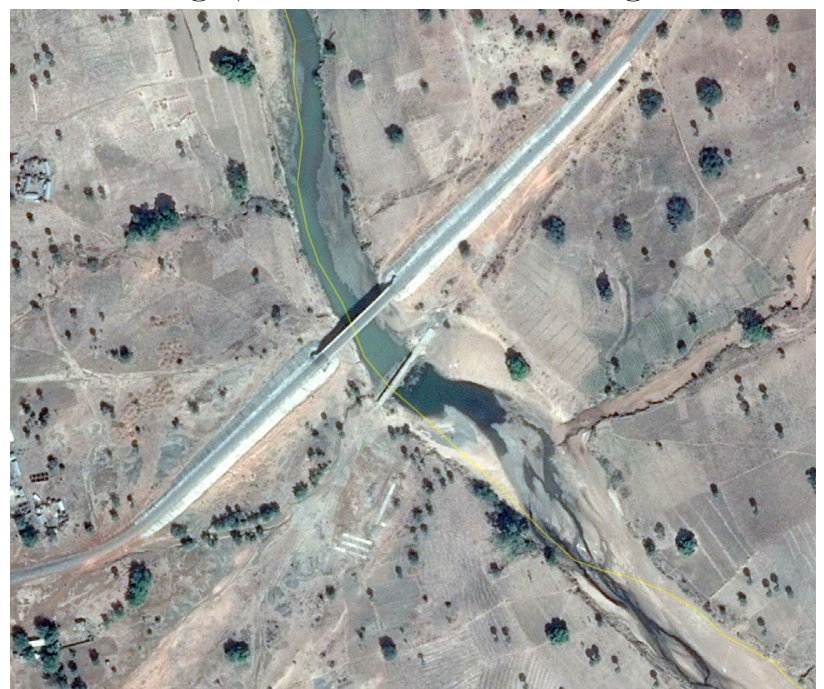

Figure 2: Images on which Border Orientation Indicators are based; "Thick" and "Thin" state presence at border crossings. Source: Google Earth. 


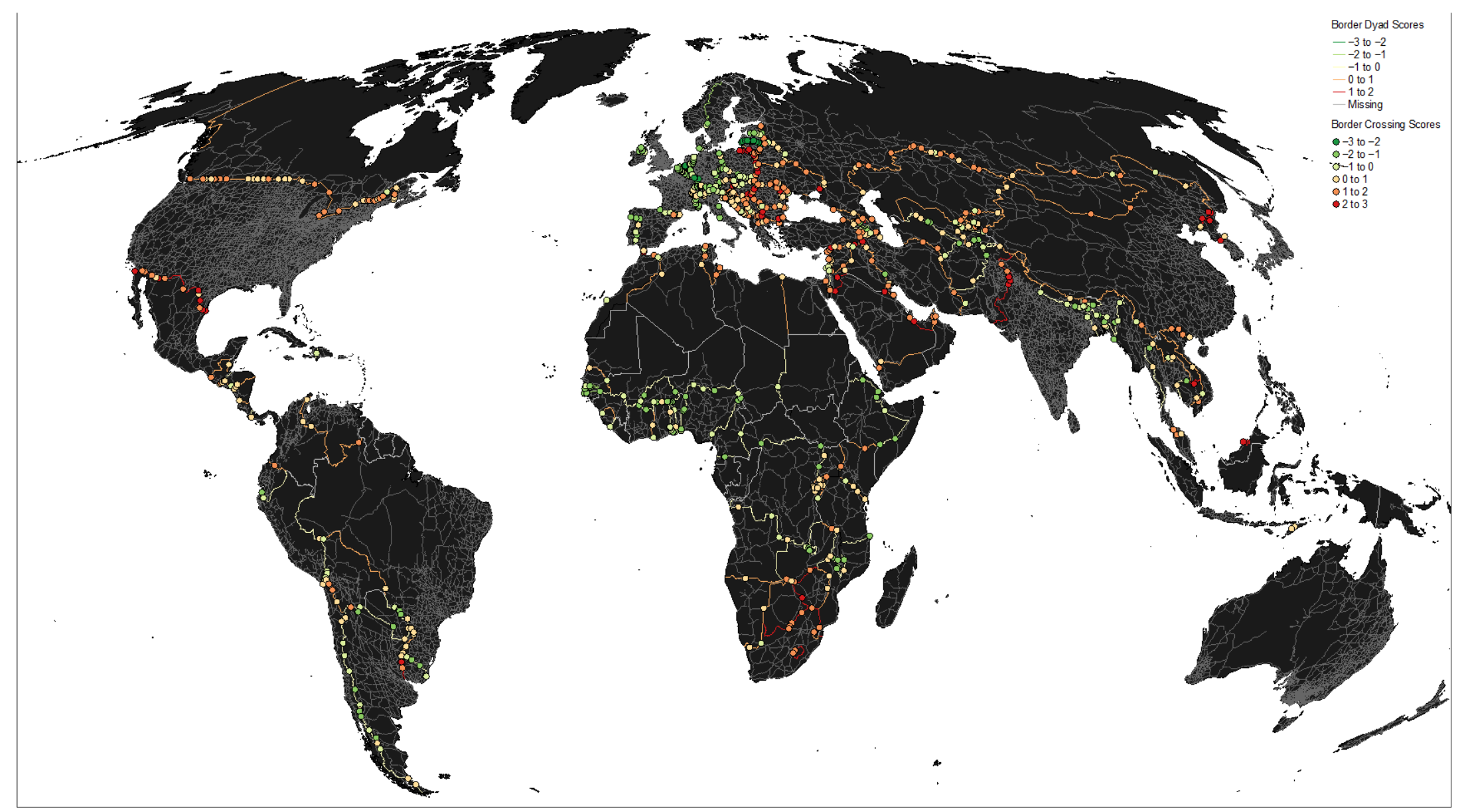

Figure 3: Border Orientation at the Level of the Border Crossing and Border Pair. Border crossings are displayed as points and border dyads are displayed as lines, scored after being residualized on a regression of GDP per capita and average elevation. Results are averaged across each side of the border. Green corresponds to permissive orientations and red to controlling orientations. Borders without major-road crossings are displayed in white and not assigned orientation score. 

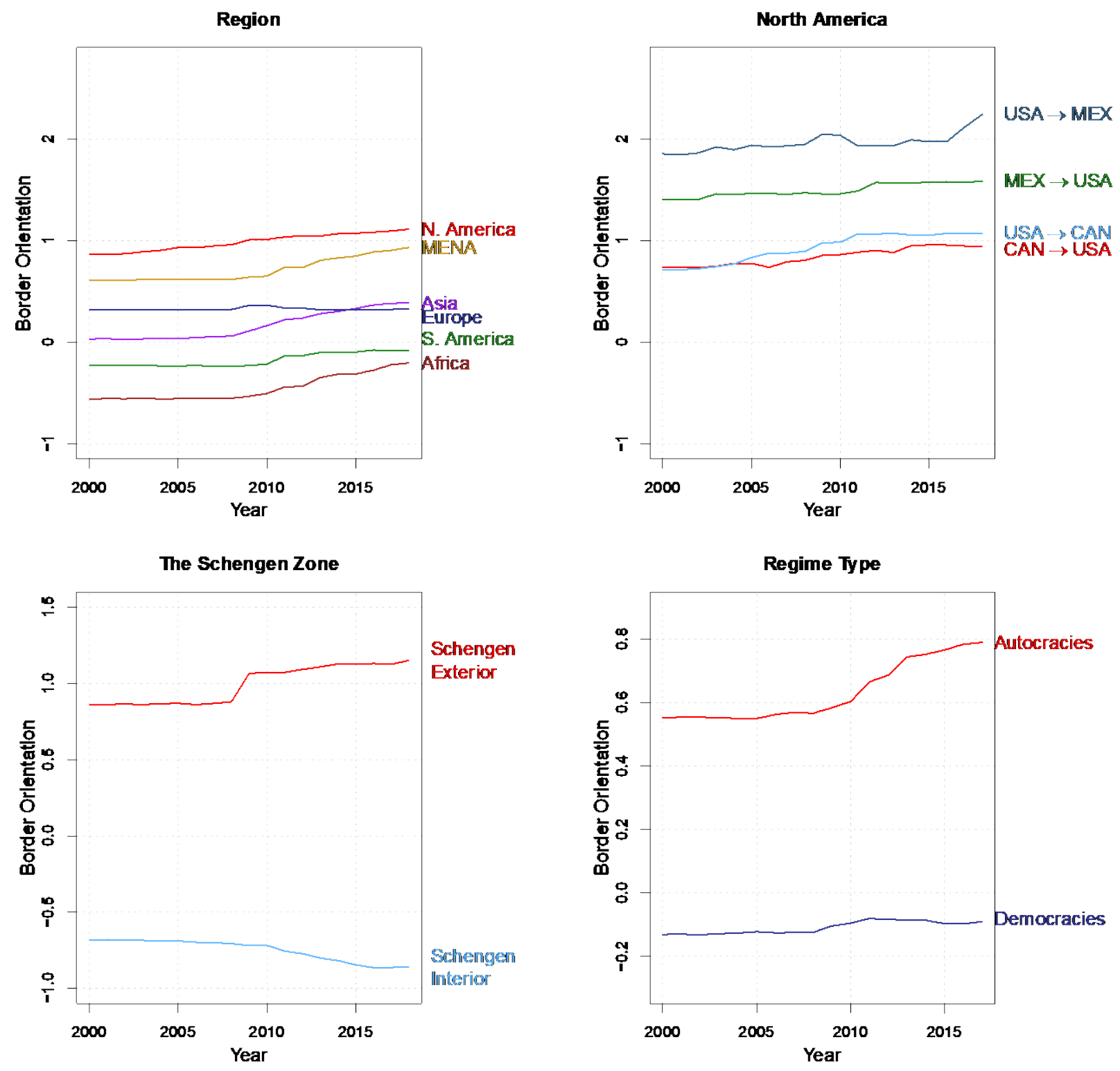

Figure 4: Border Orientation Across Time. Mean border orientation score by regime type, region, Schengen Zone status, North American borders. Shaded regions denote 95 percent credible intervals. 


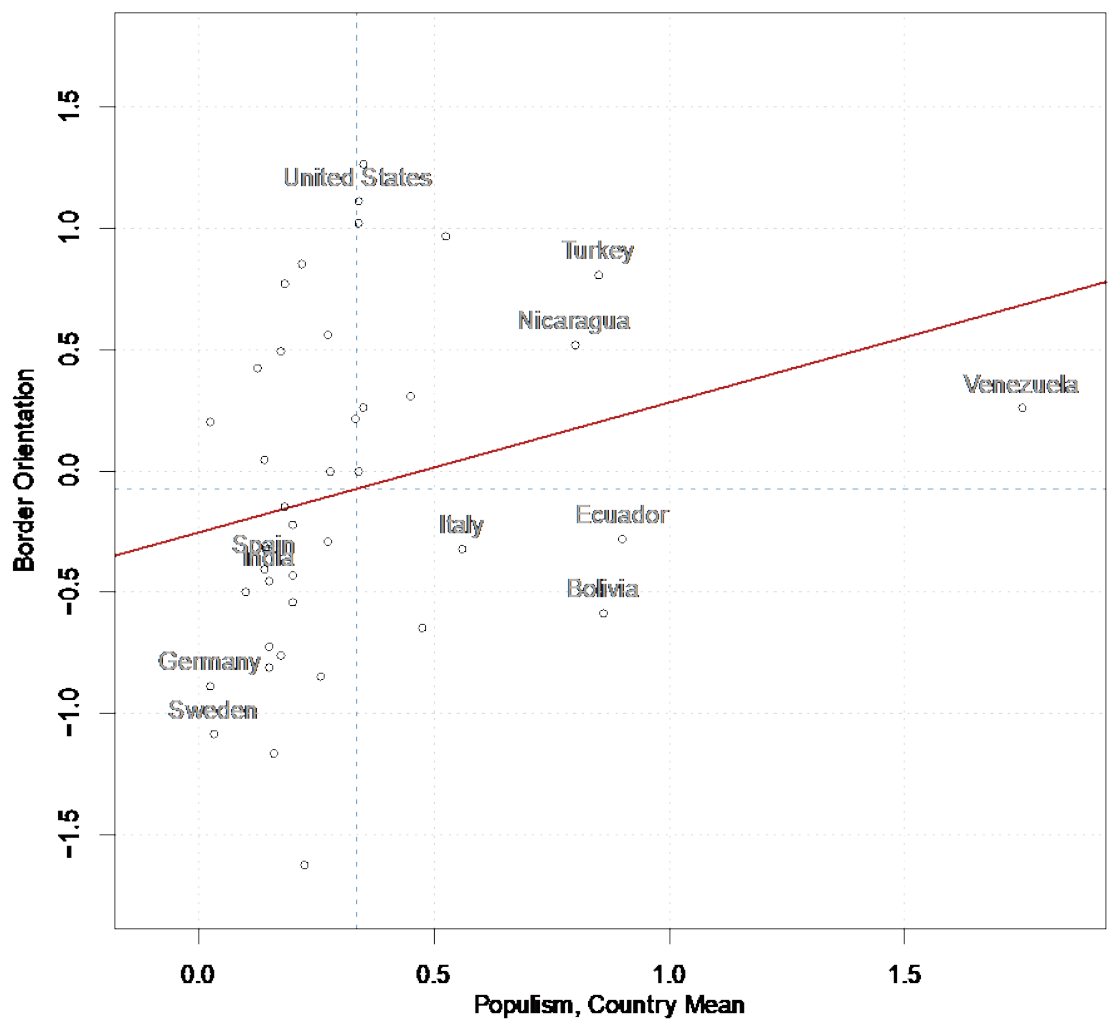

Figure 5: Populism and Border Orientation. Note the bivariate regression line in red. Border orientation is countrywide mean score for the period 2000-2018. 